\title{
Bilateral inguinal hernia in a female child
}

\author{
Ana Teresa Gil, Manuel Salgado
}

Hospital Pediátrico, Centro Hospitalar e Universitário de Coimbra, Coimbra, Portugal

\section{Correspondence to}

Dr Ana Teresa Gil, ateresagil@gmail.com
CrossMark

To cite: Gil AT, Salgado M BMJ Case Rep Published online: [please include Day Month Year] doi:10.1136/ bcr-2013-202452

\section{DESCRIPTION}

A 15-month old phenotypic female child was brought to the clinic with fever and diarrhoea. A bilateral inguinal hernia with a solid palpable mass resembling gonads was observed (figure 1). There were no other symptoms and the remaining examination was unremarkable. An ultrasound evidenced absent uterus and ovaries and confirmed the presence of bilateral inguinal testis. The karyotypic analysis revealed a 46, XY karyotype.

Bilateral inguinal hernias are rare in female infants. Incidence of complete androgen insensibility syndrome (CAIS) in these patients is $1-2 \% .^{12}$ The typical clinical presentation is either primary amenorrhoea in adolescence or inguinal swellings (later confirmed as testis) in a phenotypic female infant. $^{1}$

A patient with CAIS has the pubertal growth spurt at the appropriate age and oestrogendependent secondary sexual characters by aromatisation of androgens, with normal onset of breast development. The endocrine profile at puberty typically shows elevated serum levels of testosterone and luteinising hormone, due to the consequent lack of negative feedback. ${ }^{1}$ Body proportions tend to be female or intermediate. There is an insufficiency of secondary sexual hair growth, with pubic hair growth usually not reaching Tanner stage $5 .^{3}$

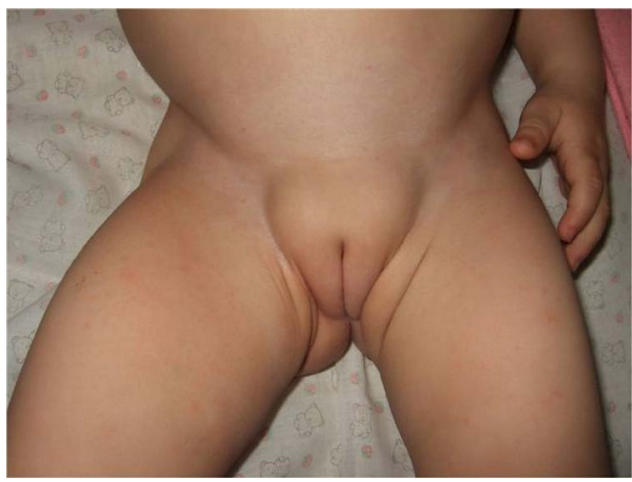

Figure 1 Bilateral inguinal hernia in a 15-month old phenotypic female child.
Management should be multidisciplinary and include gonadectomy to avoid malignant degeneration of the gonads held in the abdominal cavity, sex-hormone replacement and psychological support. ${ }^{1}$ The real risk of cancer in CAIS gonads is low before puberty, so it seems safe to leave at least one gonad in situ until completion of spontaneous puberty. ${ }^{2}$ Expected advantages are optimal development of breasts, improved bone density and preservation of self-esteem in an adolescent who will spontaneously achieve puberty.

\section{Learning points}

- Consider complete androgen insensibility syndrome (CAIS) in phenotypic female children with bilateral inguinal hernia.

- Consider CAIS in girls presenting with an inguinal gonad, even if unilaterally.

- Management of CAIS patients should be multidisciplinary and include gonadectomy, sex-hormone replacement and psychological support.

Contributors ATG developed the idea for the article, collected clinical data, performed the literature search and wrote the article. MS managed the patient, carried out the literature search, helped to collect clinical data and in writing the article.

Competing interests None.

Patient consent Obtained.

Provenance and peer review Not commissioned; externally peer reviewed.

\section{REFERENCES}

1 Hughes IA, Davies JD, Bunch TI, et al. Androgen insensitivity syndrome. Lancet 2012;380:1419-28.

2 Cheikhelard A, Morel Y, Thibaud E, et al. Long-term followup and comparison between genotype and phenotype in 29 cases of complete androgen insensitivity syndrome. $J$ Urol 2008:180:1496-501.

3 Pizzo A, Laganà AS, Borrielli I, et al. Complete androgen insensitivity syndrome: a rare case of disorder of sex development. Case Rep Obstet Gynecol 2013;2013:232696.

\footnotetext{
Copyright 2014 BMJ Publishing Group. All rights reserved. For permission to reuse any of this content visit http://group.bmj.com/group/rights-licensing/permissions.

BMJ Case Report Fellows may re-use this article for personal use and teaching without any further permission.

Become a Fellow of BMJ Case Reports today and you can:

- Submit as many cases as you like

- Enjoy fast sympathetic peer review and rapid publication of accepted articles

- Access all the published articles

- Re-use any of the published material for personal use and teaching without further permission

For information on Institutional Fellowships contact consortiasales@bmjgroup.com

Visit casereports.bmj.com for more articles like this and to become a Fellow
} 